\title{
Buffaloes and climatic change: mitigation and adaptation
}

\author{
Fayza Ibrahim Omran *
}

Address:

Animal Production Research Institute, Agricultural Research Center, Giza, Egypt

*Corresponding Author Fayza I. Omran:- fayza.omran@yahoo.com

Received: 19.01.2021; Accepted: 25.09.2021; Published: 16.10.2021

10.21608/ejar.2021.58892.1074

\section{ABSTRACT}

Climate change, especially global warming, may highly influence the production performance of farm animals throughout the world. Global warming has a great impact on the production and reproductive activity of cattle and buffaloes. The Egyptian buffalo is an important tropical species adapted to the environmental conditions in Egypt and other developed countries. In the last ten years, Egypt was exposed to waves of heat and cold which stressed the animals and decreased animal production. This was clear in 2015. So we needed animals more tolerance to stress (cold or heat) and can make modifications to micro-environmental conditions around it, faster recovery from heat stress, less water consumption, and lower methane emissions. It is more necessary to make an adaption of animals and their mitigation with environmental conditions, to decrease the adverse bad effects of climatic change in environmental conditions on animals for increasing the animal production. In this review, we discussed the roles of all environmental factors related to changes in animal production.

Keywords: Buffalo, Temperature Humidity Index, Climatic change.

\section{INTRODUCTION}

The environmental condition is a combination of several factors as temperature, humidity, rainfall, air movement, radiation, barometric pressure, and ionization. Extreme weather conditions as heat can cause substantial livestock production losses resulting in heat stress (Ghavi et al., 2013). Global warming has a great impact on the production and reproductive activity of cattle and buffaloes. It is anticipated that the temperature rise will be $1.8-4^{\circ} \mathrm{C}$ by 2100 . The Intergovernmental Panel on Climate Change IPCC (2013).

Climate change especially global warming may highly influence the production performance of farm animals throughout the world. Meanwhile, climate change is a threat to livestock production because of the impact on the quality of feed crop and forage, water availability, animal and milk production, livestock diseases, animal reproduction, and biodiversity (IPCC, 2013), the livestock sector contributes $14.5 \%$ of global greenhouse gas (GHG) emissions, driving further climate change (Gerber et al., 2013). Omran et al. (2019a) reported that the elements of animal production are diverse and interrelated thus to maintain the production of animals, the physiological modification of housing systems and animal nutrition is needed noting that each region has certain characters, the negative effects of heat stress will become more and more apparent in the future, if climatic changes continue without a solution it will be difficult to maintain animal production. In the last ten years, Egypt was exposed to waves of heat and cold which stressed the animals and decreased animal production this was Cleary in the year 2015. Omran et al. (2011a) under artificial conditions $\left(40^{\circ} \mathrm{C}\right.$ in the lab) reported that the buffalo calves exposed to heat stress were the better and faster recovery in all measurements under study Physiological, Hematological, and hormonal response, water, and feed intakes and growth rate compared with Friesian calves under as seam conditions with found Friesian under Egyptian conditions more than 60 years. Omran and Fooda (2013) under environmental conditions in Medill Egypt found that the temperature-humidity index THI >87 could be considered dangerous for Friesians, while this threshold was at THI $>91$ for Buffalo. The best THI for production in both types is lower than 68 but Buffalo starts to be under cold stress at this threshold. Friesians is colder tolerant and heats susceptible than buffalos under natural environmental Egyptian conditions. Omran et al. (2017) reported that using supplementing diets reduces the sensitivity of buffaloes to cool with climatic change under Medill Egypt conditions. Omran and Fooda (2012) reported that the buffalo calves were successful live in the reclaimed land with harsh conditions and give good production. Added to the economy, prefer fattening buffalo calves over one year.

The Egyptian buffalo is an important tropical species adapted to the environmental and managerial conditions in Egypt and other developed countries. It is the main source of milk and meat production where it contributes $45-50 \%$ and about 35 to $40 \%$ respectively. MALR (2018). The buffalo population in Egypt is about 3.7 million head according to FAOSTAT (2018). The buffalo produces $157 \mathrm{gm}$ methane per day while a cow produces $376 \mathrm{gm}$ methane per day which is $58 \%$ less than the methane emission cow, the buffalo's eco-friendly than cows (Sarubbi et al., 2013 and Appuhamy et al., 2016).

Atwa et al. (2019) reported that in Egypt buffaloes are important animals for both farmers and breeders due to it's against diseases, adaptation to harsh environmental conditions, and higher efficiency of digestion of fibers, produce a good percentage of milk fat and its milk has the best order for making Mozzarella and Raiba cheese. The primary goal of this study is to look at the impacts of climate change on buffaloes. To evaluate its environmental adaptation and mitigation, as well as to improve animal production. Also, research on the risks and effects of climate change on their water buffalo farming systems was investigated (Figure 1). 


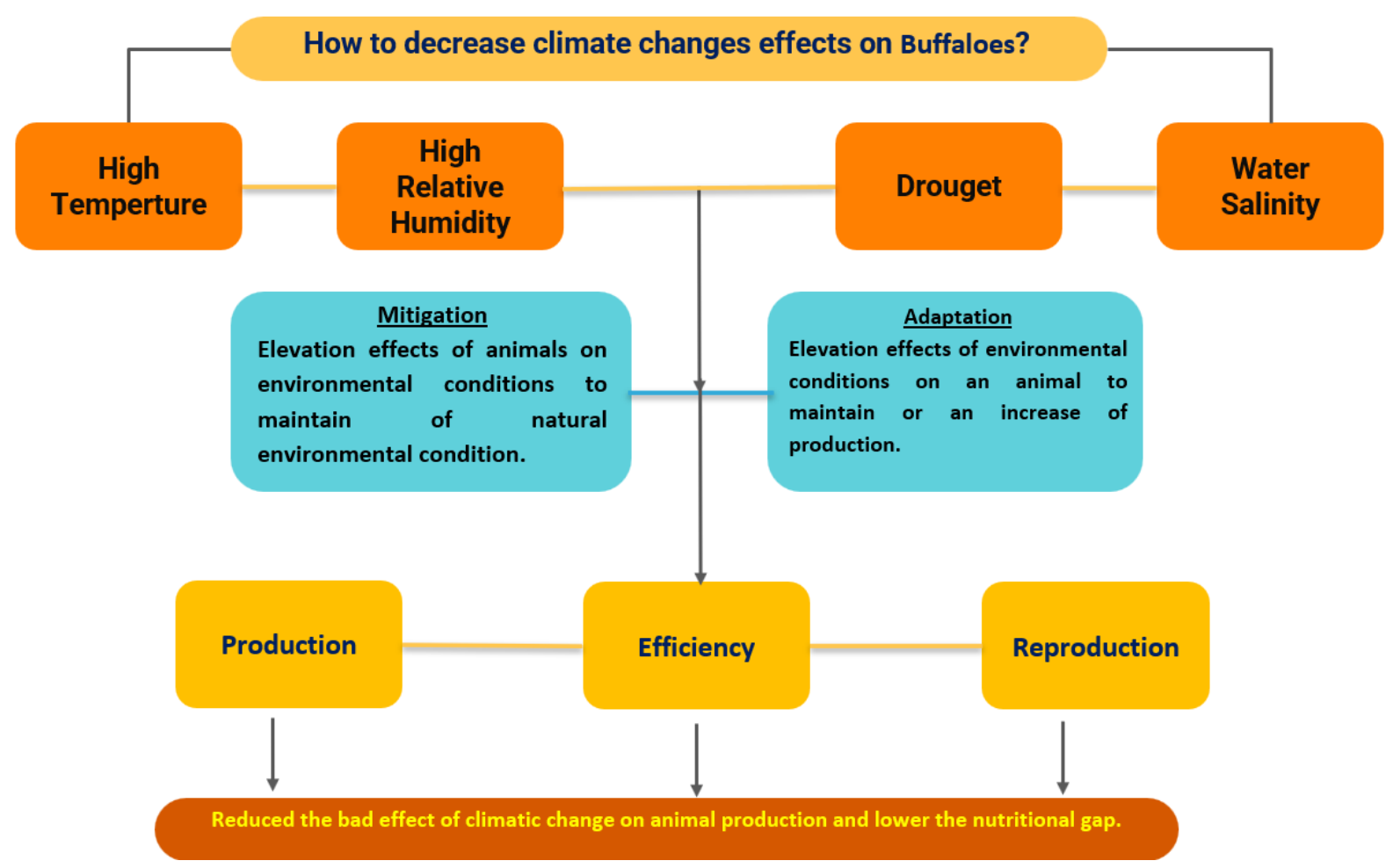

Fig. 1. The main objectives of the current review article

\section{Climatic change}

Temperature Humidity Index (THI):

The temperature-humidity index (THI) is a single value depicting the integrated effects of air temperature and humidity associated with the level of heat stress. This index has been developed as a weather safety index to control and decrease heat stress-related losses (Bohmanova et al., 2007, Omran and Fooda 2013, Omran et al., 2019b,c, e, and 2020).

The THI is a practical and useful tool for many applications in animal biometeorology. THI is extensively used in hot regions all over the world to evaluate the effect of heat stress on dairy cows and used to estimate the cooling necessities of dairy cattle to improve the efficiency of management strategies to alleviate the negative effects of heat stress (Ghavi et al., 2013). The direct impacts of air temperature, humidity, and wind speed capable of influencing growth rate, milk production, and reproduction have been reported by Rust and Rust (2013).

Khalil and Omran (2018) under environmental conditions in Egypt reported that the impact of climate change on THI values in different three regions (Lowe, Middle, and Upper Egypt) during the period 2016 up to 2060, the results give evidence for significant changes in the THI values during the period from 2046 to 2060 . The classifications of THI during the study period found that the moderate class shows a significant gradual increase with time in all studied governorates where its record highest percentage in the last studied period $(2046-2060)$ and the non-sever class percentage tends to decrease in all governorates to the account of increasing the mild and moderate heat stress classes. Omran et al. (2020) reported that the temperature-humidity index (THI) is commonly used as a relevant indicator of the degree of climatic stress on animal productivity, the classifications of the environmental regions in Egypt using this index to three regions, under Lower Egypt is climatic more stressful in comparison with Middle and Upper Egypt (due to higher of relative humidity). Moreover, the close relationship between $\mathrm{THI}$ and the tested responses including animal $\mathrm{RR} \mathrm{r} / \mathrm{min}$ and $\mathrm{Ht} \%$ in particular revealed the ability to use those parameters as predictive measures for animal acclimation in each specific region. Thus, livestock holder has the choice to select the appropriate breed for rising to get efficient productivity according to compatibility with his farm location.

Omran et al. (2019c) reported that relative humidity (RH \%) under climatic conditions of North Delta was playing an important role in increased values of a temperature-humidity index (THI). Omran and Food (2013) reported that any improvement in an animal index (THI) will ideally be useful as a base for continued development of biologic response function and representative of consequences resulting from primary factors influencing energy exchange between the animal and its surroundings., Temperature humidity index (THI) is still the best, simplest which causes stress (heat or cold) in dairy cattle and physiological parameters changing climate. Omran et al., (2019b and 2020) recommend that it is very important with climatic change, using the prediction equations which enable in maintaining water and productivity of animals without a greater drop of production. 


\section{1-Water Buffaloes:}

Two types of water buffalo are traditionally recognized worldwide, the river and the swamp buffaloes. The river buffaloes are currently widespread in Italy, few eastern European countries, the middle east, and India.

The river buffalo has been selected as a dairy animal with several recognized breeds, spread from the Indian subcontinent to the eastern Mediterranean countries (The Balkans, Italy, and Egypt). More recently river buffaloes have been imported to eastern Asia, southern America, and central Africa to improve milk production (Kierstein et al., 2004).

In Egypt, buffalo is considered an important genetic resource with great potential as a source of milk and meat. Water buffalo is the main dairy animal raised by small farmers in Egypt. Water buffaloes are found in the humid tropics and the suitability of the buffaloes to the hot climatic conditions is shown to be achieved by morphological, anatomical, and physiological characteristics (Shafie, 1993a and b, Shafie and Omran, 2018, Omran, 2013 a,b, Omran et al., 2013 and Omran and Fooda, 2013).

Shafie and Omran (2018) reported that the buffalo can change the morphology and histology of their skin to maintain bioprocesses, and the size of the surface area to the animal's body and skin color show special adaptation to environmental factors. And the differences may simply be a reflection of the animal's environment; this pattern might indicate an adaptation to their environment and not genetically associated.

Many local buffalo populations show wide variation in their size and color, but none of these is believed to be according to separate breed (Borghese, 2011) this agreement with Omran et al. (2019d) reported that higher significant phenotypic and morphometric variations were found between buffalo populations raised under Nile Delta (ND) and Nile Valley (NV) under environmental climatic conditions in Egypt. In addition to the temperature-humidity index (THI) was playing a prominent role in the variation of size between buffalo under different thermal conditions.

\section{1- Buffalo skin:}

The Buffaloes have sparse hair coat particularly with age progress. Collier et al. (2006) found that skin temperature is highly correlated with respiration rates and it is a good tool to measure the microenvironment around the animals. They also added that, if the skin surface temperature is below $35{ }^{\circ} \mathrm{C}$, the temperature gradient between the core and skin is large enough for the animals to effectively use all routes of heat exchange. This agreement with Omran and Hamdon (2018).

Shafie and Omran (2018) reported that buffalo under two different thermal artificial conditions had the total number of hair per $\mathrm{cm} 2\left(449.50\right.$ and 915.00 in a lab) $\left(A\right.$ at $\left.40^{\circ} \mathrm{C}\right)$ and lab $\left(B\right.$ at $\left.25^{\circ} \mathrm{C}\right)$, respectively. This decreased number of hairs under heat stress to easily distribute heat to decrease the load of the higher temperature and the morphological characteristics of hair coat are markedly influenced by climate as observed in (Table1).

Table (1). Morphological changes of hair and skin of buffalo calves due to exposed to two different thermal artificial conditions at $40{ }^{\circ} \mathrm{C}\left(\right.$ Lab A) and $25^{\circ} \mathrm{C}$ (Lab B). (Shafie and Omran, 2018).

\begin{tabular}{|c|c|c|}
\hline Item & Group $(\mathrm{A}), 40^{\circ} \mathrm{C}$ & Group (B), $25^{\circ} \mathrm{C}$ \\
\hline $\begin{array}{l}\text { Hair } \\
\text { Hair color } \\
\text { Hair texture } \\
\text { Hair length } \\
\text { Distribution of hair on the body } \\
\text { Hair density }\end{array}$ & $\begin{array}{c}\text { Wooden color } \\
\text { Rough } \\
\text { Long } \\
\text { Sparse and there are parts of the } \\
\text { hair-free } \\
\text { Slight }\end{array}$ & $\begin{array}{c}\text { Light Gray } \\
\text { Soft } \\
\text { Short } \\
\text { Harmonic and covered } \\
\text { the body } \\
\text { Heavy }\end{array}$ \\
\hline $\begin{array}{l}\text { Skin } \\
\text { Skin color } \\
\text { Skin texture } \\
\text { Sebum substance }\end{array}$ & $\begin{array}{c}\text { Tends to redness } \\
\text { Wet } \\
\text { Find }\end{array}$ & $\begin{array}{l}\text { Dark gray } \\
\text { Dry } \\
\text { Not find }\end{array}$ \\
\hline
\end{tabular}

The hair was soft, short, heavy, and harmonic under conditions in a lab (B) while under conditions in a lab (A) was rough, long, slight and this results in agreement with Omran et al. (2019d) under environmental conditions in Nile Delta and Nile Valley. The actual density of hairs is less than that of follicles due to the phenomenon of hair shedding (Shafie, 1985) so that the adult hair is scattered sparsely and all provide no insulation in comparison to the young buffalo which have a complete cover.

Therefore, heat dissipation in these animals would be seriously hampered unless it quires a special behavior to moisten its surface from outside water such as by swimming and wallowing. The great effect of direct solar radiation on the sebum secretion in buffaloes followed by Friesians and then the other cattle breeds could be attributed to the black skin in the former two breeds., However, the buffaloes showed a negative reaction to solar radiation by decreasing the sebum secretion while cattle bread showed positive reaction. Shafie and Omran (2018) Addition that, the development of the size sweet, sebaceous glands, and thickness of epidermis and dermis were decreased in a group (A) comparative with grope (B). while a total of hair follicles number increased in group B than group A by filed $3.11(\mu)$ but the length of hair follicles and length of hair was higher in a group (A) comparative with a group (B) this development increase the efficiency of animal to microclimatic conditions around them. 
Table (2). Thickness of epidermis $(\mu)$ and Dermis $(\mu)$, total number of hair follicles filed $(\mu)$, length of hair follicles $(\mu)$, length of hair $(\mu)$, number of sebaceous gland filed $(\mu)$ and number of sweat gland filed $(\mu)$ of buffalo calves due to exposure to two different thermal artificial conditions at $40{ }^{\circ} \mathrm{C}\left(\right.$ Lab A) and $25^{\circ} \mathrm{C}$ (Lab B). (Shafie and Omran, 2018)

\begin{tabular}{|l|c|c|}
\hline \multicolumn{1}{|c|}{ Item } & Group $(\mathbf{A}), \mathbf{4 0}{ }^{\circ} \mathbf{C}$ & Group (B), 25 ${ }^{\circ} \mathbf{C}$ \\
\hline Thickness of epidermis $(\boldsymbol{\mu})$ & $2.09 \pm 0.12^{\mathrm{b}}$ & $4.22 \pm 0.16^{\mathrm{a}}$ \\
\hline Thickness of Dermis $(\boldsymbol{\mu})$ & $90.45 \pm 1.74^{\mathrm{b}}$ & $105.05 \pm 2.55^{\mathrm{a}}$ \\
\hline total number of hair follicles filed $(\boldsymbol{\mu})$ & $3.35 \pm 0.23^{\mathrm{b}}$ & $6.47 \pm 1.04^{\mathrm{a}}$ \\
\hline Length of hair follicles $(\boldsymbol{\mu})$ & $26.0 \pm 1.83^{\mathrm{a}}$ & $18.36 \pm 0.00^{\mathrm{b}}$ \\
\hline Length of hair $(\boldsymbol{\mu} /$ filed) & $9.67 \pm 0.33^{\mathrm{a}}$ & $3.00 \pm 0.00^{\mathrm{b}}$ \\
\hline number of sebaceous gland filed $(\boldsymbol{\mu})$ & $3.38 \pm 0.37^{\mathrm{a}}$ & $3.50 \pm 0.42^{\mathrm{a}}$ \\
\hline number of sweat gland filed $(\boldsymbol{\mu})$ & $4.17 \pm 0.60^{\mathrm{a}}$ & $3.75 \pm 0.48^{\mathrm{a}}$ \\
\hline
\end{tabular}

Mean values in the same row with different superscripts are significantly different $(P<0.05)$.

The thickness of the skin has increased the alarm for the sensory nerves, which increases the speed of skin alarm hypothalamus (central nervous system) to increase the efficiency of tensor hair and increase blood Supply in the surface layer of the skin, which increases the speed of loss the heat from the body temperature, due to the blood supply was the biggest and more in-group (A) compared to group (B).

\section{2- Buffalo rumen:}

Under heat stress in a lab at $40^{\circ} \mathrm{C}$ and $25^{\circ} \mathrm{C}$, Omran et al. (2011b) reported that the rumen plays a certain role in the adaptation process the greater volume of water content in the rumen compared to the case in the single stomach has a significant role in evaporative cooling of the animal body during hot conditions. In addition to the large volume of water due to the high specific heat capacity of water, it absorbs a lot of any excessive heat from the endangered body tissues. Also see the average weight of the rumen fresh tissue were $2.5 \pm 0.05$ and $4.75 \pm 0.14 \mathrm{~kg}$, respectively and the average weight of abomasum's tissue were $1.09 \pm 0.12$ and $0.94 \pm 0.19 \mathrm{~kg}$, concomitant with increased feed intake $\mathrm{Fl} / \mathrm{Kg}$ during trial two in a lab under heat stress compared with trail one and this reflected on the daily gain from decreased by $(-0.49 \mathrm{~kg} / \mathrm{day})$ to increase by $(+0.03 \mathrm{~kg} / \mathrm{day})$ at the scanted exposure heat stress in lab.

Omran (2013a) under different thermal conditions for buffalo calves in Lab at $40^{\circ} \mathrm{C}$ groups ( A) and $25^{\circ} \mathrm{C}$ groups (B) reported that the water capacity was lower compared with several respiration rates under stress in a minute, this gives an indicator to performance of buffalo calves to maintain on body temperature by losing low quantity from water.

These differences between groups indicated that in heat stress buffalo calves maintained their body temperature by losing a quantity of RWC/L day and increased respiration rate (RR r/min)., heat stress reduced feed intake $(\mathrm{Fl} / \mathrm{Kg})$ and increased water intake (WI/L/day) and respiration rate ( $\mathrm{RR} \mathrm{r} / \mathrm{min}$ ) (Table 3$)$.

Table (3). Feed intake (FI, kg), respiration rate (RR, r/min), water intake (WI, L) and rumen water capacity (RWC, L) for two groups (A \& B) in buffalo calves exposed to different thermal condition. (Omran, 2013a).

\begin{tabular}{|l|c|c|}
\hline \multicolumn{1}{|c|}{ Items } & Group (A) $40^{\circ} \mathbf{C}$ & Group (B) $\mathbf{2 5}^{\circ} \mathbf{C}$ \\
\hline Feed intake (kg): & & $4.8 \pm 0.14^{\mathrm{a}}$ \\
Concentrate (Con.) & $2.5 \pm 0.0^{\mathrm{b}}$ & $1.0 \pm 0.0^{\mathrm{a}}$ \\
Wheat straw (R1) & $0.5 \pm 0.0^{\mathrm{b}}$ & $0.22 \pm 0.03^{\mathrm{a}}$ \\
Barseem hay (R2) & $0.16 \pm 0.03^{\mathrm{a}}$ & $20.0 \pm 0.35^{\mathrm{b}}$ \\
Respiration rate (RR) & $122.0 \pm 1.62^{\mathrm{a}}$ & $26.0 \pm 0.48^{\mathrm{a}}$ \\
Water intake (WI, L) & $20.0 \pm 1.25^{\mathrm{b}}$ & $32.7^{\mathrm{a}}$ \\
\hline
\end{tabular}

In the same row means with different superscripts are significantly different $(\mathrm{P}<0.05)$.

In addition to, the changing of histology rumen under differing thermal conditions in Table (4 and 5) This difference between the two groups increased efficiency of animal to lives under heat stress condition by abundant change of tissue with decreased or increased of a thickness of layers in response to heat stress, the density of papillae, length and diameters of papillae increased of total absorbed of feed digested so, any improved of quality of feed increased of microbial fermentation due to increase the total observed this lower effect of a decrease in the production of an animal under heat stress. 
Tables (4). Thickness of the different layers of rumen and abomasum $(\mu)$ tissues for the two experimental groups (A \& B) in buffalo calves exposed to different thermal condition. (Omran, 2013a).

\begin{tabular}{|c|c|c|}
\hline Items & Group (A) $40^{\circ} \mathbf{C}$ & Group (B) $25^{\circ} \mathbf{C}$ \\
\hline Rumen : & & $82.2 \pm 3.29$ a \\
Tunica muscular & $54.2 \pm 1.7^{\mathrm{b}}$ & $16.7 \pm 0.58^{\mathrm{b}}$ \\
\hline Mucosa & $19.2 \pm 0.59^{\mathrm{a}}$ & $25.8 \pm 0.49^{\mathrm{b}}$ \\
\hline Abomasums : & & $23.7 \pm 1.4^{\mathrm{a}}$ \\
Tunica muscular & $49.8 \pm 3.9^{\mathrm{a}}$ & $33.0 \pm 0.6^{\mathrm{a}}$ \\
\hline Sub mucosa & $21.6 \pm 1.5^{\mathrm{a}}$ & $26.9 \pm 0.6^{\mathrm{b}}$ \\
Mucosa &
\end{tabular}

In the same row means with different superscripts are significantly different $(\mathrm{P}<0.05)$.

Table (5). Measurements of rumen papillae in two experimental groups (A \& B) of buffalo calves exposed to different thermal conditions. (Omran, 2013a).

\begin{tabular}{|l|c|c|}
\hline \multicolumn{1}{|c|}{ Items } & Group (A) $40^{\circ} \mathbf{C}$ & Group (B) $\mathbf{2 5}^{\circ} \mathbf{C}$ \\
\hline Number of papillae $/$ field & $17.0 \pm 0.58^{\mathrm{b}}$ & $20.0 \pm 0.47^{\mathrm{a}}$ \\
Length of papillae $(\boldsymbol{\mu})$ & $41.3 \pm 7.3^{\mathrm{a}}$ & $48.8 \pm 3.5^{\mathrm{a}}$ \\
Diameter of papillae $(\boldsymbol{\mu})$ & $18.3 \pm 0.8^{\mathrm{b}}$ & $23.19 \pm 1.0^{\mathrm{a}}$ \\
Space between papillae $(\boldsymbol{\mu})$ & $26.9 \pm 2.8^{\mathrm{a}}$ & $13.7 \pm 3.5^{\mathrm{b}}$ \\
Papillae surface aria/field $\left(\boldsymbol{\mu}^{2}\right)$ & $11892.47 \pm 2717^{\mathrm{b}}$ & $22974.46 \pm 2576^{\mathrm{a}}$ \\
Total surface papillae area $/$ field $\left(\boldsymbol{\mu}^{2}\right)$ & $202062.1 \pm 41532^{\mathrm{b}}$ & $439443.2 \pm 47511^{\mathrm{a}}$ \\
\hline
\end{tabular}

In the same row means with different superscripts are significantly different $(\mathrm{P}<0.05)$.

Field, $\mu^{2}=20096 \quad$ Field, $\mathrm{cm}^{2}=0.61544$

\section{3- Physiological and haematological responses for buffaloes under thermal conditions:}

Under heat stress, the animal behavioral and physiological responses are initiated to increase heat loss and reduce heat production in an attempt to maintain body temperature within the range of normality $\left(38.3-38.7^{\circ} \mathrm{C}\right)$.

Many investigators reported that Thermo-physiological responses, rectal temperature $\left(R T,{ }^{\circ} \mathrm{C}\right)$, and respiration rate $(R R$, $\mathrm{r} / \mathrm{min}$ ) are good measures to detect the response of an animal to variation in the microenvironment around the animal thus giving clear evidence of the better capacity of heat tolerance (Ashour et al., 2004, Omran and Fooda 2013, Omran and Hamdoon (2018) and Omran et al., 2013, 2017, 2020). Omran et al. (2020) under different regions climatic conditions in Egypt on buffaloes and cows reported that increased respiration rate RR $\mathrm{r} / \mathrm{min}$ is the first reaction when animals are exposed to an environmental temperature above the thermo-neutral zone; this response ensures direct heat stimulation of the peripheral receptors which transmit nervous impulses to the heart center in the hypothalamus, and the values of RR $\mathrm{r} / \mathrm{min}$ were relatively higher in the young animals as compared with the older animals of both buffaloes and cows. However the variance in $R R \mathrm{r} / \mathrm{min}$ between age categories of cows was increasing in concomitant with the higher seasonal temperatures the values of RR r/min for both species were the highest at Lower Egypt (LE) followed by Middle Egypt (ME) and Upper Egypt (UE), the differences between two species in $\mathrm{RR} \mathrm{r} / \mathrm{min}$ were highly significant so that the range of $\mathrm{RR} \mathrm{r} / \mathrm{min}$ in cows lies between 39.3-54.6 r/min while in buffaloes it was 32.3- $40.5 \mathrm{RR} \mathrm{r} / \mathrm{min}$. This finding clarified the ability of buffaloes to dissipate the influence of heat stress through different internal mechanisms.

Also reported that animal $\mathrm{RR} \mathrm{r} / \mathrm{min}$ is a faster indicator of any changes in the microenvironment when compared with the slow alterations in skin temperature $\left(\mathrm{ST}{ }^{\circ} \mathrm{C}\right)$. On the other side, hematocrit value $(\mathrm{Ht} \%)$ is a sensitive indicator to the surrounding thermal conditions when compared with hemoglobin $(\mathrm{Hb}, \mathrm{g} / \mathrm{dl})$ concentrations reason for the thermal conditions around animals. Therefore, $\mathrm{RR} \mathrm{r} / \mathrm{min}$ and $\mathrm{Ht} \%$ can be used as a good and faster indicator of animal stressed.

The Hematological parameters represent a fine mirror that reflects healthy conditions of the animal most species of domestic animals have $\mathrm{Ht} \%$ values from ( 38 to $40 \%$ ).

The Hemoglobin $\mathrm{Hb} g / \mathrm{dl}$ values decreased as a result of exposing animals to high air temperature $\left(\mathrm{AT}{ }^{\circ} \mathrm{C}\right)$ in a lab or under normal environmental conditions (Ashour et al., 2004 and Omran et al., 2013).

Omran et al. (2011a, c, 2013, 2020 and Omran and Hamdoun (2018) reported that blood pictures for buffalo calves showed a clear drop in $\mathrm{Ht} \%$ and $\mathrm{Hb} \mathrm{g} / \mathrm{dl}$ values and increased count of white blood cells count (WBCsx10/mm)) under heat stress. Such change may refer partially to hemodilution by the excess water intake (WI/L/day).

The drop in $\mathrm{Hb} \mathrm{g} / \mathrm{dl}$ and $\mathrm{RBCs} \times 10 / \mathrm{mm}$ was more pronounced than the decline in value $\mathrm{Ht} \%$ which indicates other mechanisms imposing a drop in $\mathrm{Hb} \mathrm{g} / \mathrm{dl}$ and $\mathrm{RBCsx} 10 / \mathrm{mm}$ to reduce oxidation activity of metabolism followed by a drop in metabolic heat production.

The white blood cells WBCsx10/mm count was increased as an indication of higher immunological activity. The author attributed the higher estimates of $\mathrm{Ht} \%$ and $\mathrm{Hb} \mathrm{g} / \mathrm{dl}$ in buffaloes to adaptability of the animal and fast recovery from heat stress as compared with Friesian denoting the buffaloes can alleviate the heat stress through evaporation from the skin and the respiratory system. Omran et al. (2011d) reported that responses of leukocyte cell types (LCT\%) difference in five types due to exposure to heat stress (HS) the changes occurred in the percentage of Lymphocytes (Ly\%) decreased and Neutrophils (Ne\%) increased, eosinophil's (Eo\%) increased and monocytes (Mo \%) decreased and these values were higher in Frisian calves (FC) than buffalo calves (BC) Ne \% was higher in FC than BC and ( Ly\%) lower in FC than BC due to adaptability in $\mathrm{BC}$ compared to FC for high temperature, values of the ratio $\mathrm{Ne} / \mathrm{Ly} \%$ was significant between two breed. 
Omran (1999) under natural environmental conditions reported that the average values in Buffalo calves for $\mathrm{Ne} \%$ and $\mathrm{Ly} \%$ were $58.3 \% \& 34.1 \%$ in winter compared to that in summer $56.98 \%, 35.4 \%$. In FC respective values were $56.8 \%, 35.4$ in winter, and $60.4 \% \& 29.5 \%$ in summer this change agreement with, Ashour et al. (2004).

\section{4- Blood metabolites, mineral ions and hormonal profile:}

The tolerance capacity of Egyptian buffaloes was determined in Egypt under natural seasonal conditions and artificial laboratory conditions of heat stress at $40^{\circ} \mathrm{C}$ (lab A), and comfort state at $25^{\circ} \mathrm{C}$ (lab B) by Omran (2011d) on buffalo calves reported that blood plasma metabolites to heat stress showed great decrease in total lipids (TL, mg/dl), triglycerides (TC, $\mathrm{mg} / \mathrm{dl}$ ) followed by glucose (Glu, $\mathrm{mg} / \mathrm{dl}$ ). These reductions indicated hamper of metabolic activities subsequently less product of metabolic heat. The drop in total protein (TP, g/dl) suggests an effect of hemodilution along with the drop in buildup of plasma proteins, the increase in globulin (Glo, g/dl) against a drop in albumin (Alb, g/dl) indicates control in colloid osmotic pressure to maintain proper blood circulation. The level of blood urea nitrogen (BUN, $\mathrm{mg} / \mathrm{dl}$ ) was also significantly lowered in group A than in group B during the two trials in response to heat stress. Also reported heat stress caused increasing in concentration of Potassium (K, mg/dl), sodium $(\mathrm{Na}, \mathrm{mg} / \mathrm{dl}$ ) around $10 \%$ opposite to $20 \%$ decrease in calcium (Ca, mg/dl). The phosphorus ( $P, \mathrm{mg} / \mathrm{dl}$ ) showed a more than $50 \%$ increase this increase should be, particularly, due to hem concentration by activated water vaporization from the animal's surfers and increased respiratory vaporization.

Nevertheless, the difference in the rate of increase between $\mathrm{K}, \mathrm{Na}$, and $\mathrm{P}$ indicated active physiological arrangements concomitant with the hem concentration. The opposite trend by a reduction in $\mathrm{Ca}$, equal in the two treatments, emphasizes effective physiological interference. In addition to heat stress caused reduction in insulin (Ins, ulu/ml) concentrations, coincidentally, the glycogen $(\mathrm{Glg}, \mathrm{pg} / \mathrm{ml}$ ) concentration increased. These hormones indicate hormonal control on a critical drop in Glu concentration. in blood plasma under heat stress ( 47 and $40 \mathrm{mg} / \mathrm{dl}$ ) in comparison to (79 and $75 \mathrm{mg} / \mathrm{dl}$ ) under comfort conditions, and it is clear that triiodothyronine $\left(T_{3}, \mathrm{ng} / \mathrm{dl}\right)$ and thyroxin $\left(\mathrm{T}_{4}, \mathrm{ug} / \mathrm{dl}\right)$ hormone concentration were decreased more than $50 \%$ in response to heat stress, almost with equal levels in two trials in lab, devoting depression in general metabolic activity, thus metabolic heat production (Ashour et al., 2000, Omran et al., 2011b). Shaffer et.al, (1981) identified a highly significant effect of seasonal temperature on blood glucose levels. El-Masry and Habeeb (1989) reported that high air temperature caused a drop in insulin this agreement with (Omran, 2011d and Ashour et al., 2004) there reported that high air temperature caused a drop in insulin.

\section{5- chemical components, physical characteristics, histology and Meat quality:}

The nutritional value of buffalo meat is higher than that of beef; it has a much lower fat and cholesterol content and is a highly concentrated source of protein, It contains almost all the essential amino acids needed for human health, a high concentration of A and B vitamins. It is also an important source of iron, copper, zinc, and selenium (Rebak et al., 2010).

Omran (2013b) under artificial heat stress in ( lab A at $40^{\circ} \mathrm{C}$ ) reported that the area of longissimus dorsi muscle decreased by $17 \%$, and this area $/ \mathrm{Kg}$ was more by $20 \%$ in the comfort group (B) more than in stressed group (A) in a lab, the effect of heat stress on the meat chemical component; the values of sodium( $\mathrm{Na})$, potassium $(K)$ and phosphorus $(\mathrm{p})$ were higher under heat stress while the values of iron I and calcium ( $\mathrm{Ca}$ ) were lower in blood., the level of Ca was decreased in meat under heat stress may be due to mechanism of $\mathrm{Ca}$ in activated dependent protease (CDP) systems to activation or inhibitor enzymatic activity causes to tenderness in meat under heat stress and this agreement with Whipple et al. (1999).

While the value of Na was higher under heat stress the increase of Na may be due to an increase in blood with heat stress and the decrease of $\mathrm{Ca}$ in meat Omran (2008). Then fined relationship between levels of $\mathrm{Na}$ to $\mathrm{K}$ and $\mathrm{Ca}$ to $\mathrm{P}$ in the blood to maintained and balance in all biological processes in the body. the protein and ash in meat were higher, while the lipid was lower, the color of meat was light, and the tenderness and taste were excellent as the veal with level from protein high and low lipid, low level of moisture (\%) due to decrease the loss cooking., Thus all these needs by the consumer taste and healthily, heat stress don't effect of quality of meat and give meat good to the consumer. Rebak et al. (2010) found that in normal meat buffalo, the values of crude protein, lipids, and ash were 70.1, 11.13, and 3.39, respectively. Omran (2013b) reported that the exposure of buffaloes to heat stress doesn't affect levels of protein and ash but decreases the level of fat, the biological value of meat buffalo don't affect by heat stress (Table 6).

Table (6). Chemical analysis of longissimus dorsi (LD) for two meat buffalo calves groups exposure under $40^{\circ} \mathrm{C}(\mathrm{A})$ and $25^{\circ} \mathrm{C}(\mathrm{B})$. (Omran, 2013b).

\begin{tabular}{|c|c|c|}
\hline \multirow[t]{2}{*}{ Items } & Group $A\left(40^{\circ} \mathrm{C}\right)$ & Group B $\left(25^{\circ} \mathrm{C}\right)$ \\
\hline & Mean \pm SE & Mean \pm SE \\
\hline Protein & $71.07 \pm 0.87^{a}$ & $69.15 \pm 2.24^{a}$ \\
\hline Lipid & $5.64 \pm 0.96^{b}$ & $19.71 \pm 0.78^{a}$ \\
\hline Ash & $14.30 \pm 1.07^{a}$ & $6.81 \pm 2.39^{b}$ \\
\hline Moisture & $22.90 \pm 2.70^{\mathrm{a}}$ & $23.20 \pm 2.30^{\mathrm{a}}$ \\
\hline Sodium ( $\mathrm{Na}, \mathrm{mM} / \mathrm{L}$ ) & $0.55 \pm 0.11^{\mathrm{a}}$ & $0.170 \pm 0.03^{b}$ \\
\hline Potassium (K, mM/L) & $26.80 \pm 0.17^{a}$ & $26.97 \pm 0.170^{a}$ \\
\hline Calcium (Ca, mM/L) & $3.07 \pm 0.03^{b}$ & $3.80 \pm 0.060^{\mathrm{a}}$ \\
\hline Phosphor (P, mg/dl) & $0.63 \pm 0.12^{b}$ & $1.83 \pm 0.030^{\mathrm{a}}$ \\
\hline
\end{tabular}

In the same row means with different superscripts are significantly different $(P<0.05)$. 
Added to study physical characteristics; the color intensity of meat under heat stress (lab A) as like the meat veal (pink) while under comfort conditions the color was red as like the meat for calving greater than a year the first due to decreased of level in Iron in the blood comparative with iron under comfort conditions (lab B) this reflected of the color due to the values of hemoglobin $(\mathrm{Hb})$ is blood-related to the level iron in the blood under heat stress animals reduced the $\mathrm{Hb}$ content in their blood to check the metabolic rate, thus reducing the production of metabolic heat. The decrease of the feed intake and metabolic due to decrease of all blood components thus the lower value of iron under heat stress. The red color of meat is light due to myoglobin which is a protein very similar in properties to blood hemoglobin. Addition to, the chemical and physical characteristic was good under heat stress, the tenderness and fiber under stress were smooth and the fiber was thin and coherent while under comfort conditions the meat was rough and the fiber was stretch and disjointed and the tenderness was high under heat stress comparative with comfort during the meat the chewing and the best taste test (Table 7).

Table (7). Physical characteristics for two meat buffalo calves groups exposure under $40^{\circ} \mathrm{C}$ (A) and $25^{\circ} \mathrm{C}$ (B). (Omran, 2013b).

\begin{tabular}{|l|c|c|}
\hline \multicolumn{1}{|c|}{ Items } & Group A $\left(\mathbf{4 0} \mathbf{\circ}^{\circ} \mathbf{C}\right)$ & Group B (25 $\left.{ }^{\circ} \mathbf{C}\right)$ \\
\hline Color & Pink & Red \\
Tenderness & High & + \\
The cooking loss & + & Medium \\
Meat quality after cooking & High & + \\
\hline
\end{tabular}

The tenderness and fibers with histology explain that they found significant between heat stress and comfort condition the intermediate connective tissue (collagen fiber) was higher under heat stress.

The histology and physical characteristics explain the meat quality; the fiber package diameter, fine fiber diameter, and intermediate connective tissue (collagen) were higher under heat stress and lower the connective tissue, buffalo calves under heat stress try decrease of energy from the body, for this reason, the calves reaction maybe merge the fiber to lower thin the mussels to decrease the effect of heat stress, this clear on an area of longissimus dorsi under heat stress compared comfort conditions by $3.3 \mathrm{~cm}$ and the higher of collagen fiber under heat stress reflect on the good quality of meat due to increase of this fiber is beast to cooking.

\section{8- Housing system:}

Housing System is mainly designed to suit the requirements of temperature climate and has proved unsuitable for tropical climates. The system of the house reduced the effect of environmental conditions on animals and the effects of animals on environmental conditions (adaption and mitigation). Thomas and Sastry (1991) reported that the shelter system not only fulfils its principal function but also providing to health-sustaining and comfortable environment to animal behavioral and physiological responses that are initiated to increased heat loss and reduce heat production in an attempt to maintain body temperature within the range of normality. The significance of the increase of the respiration rater $\mathrm{RRr} / \mathrm{min}$ under heat stress is that it enables the animals to dissipate the excess of body heat by vaporizing more moisture in the expired air, which accounts for about $30 \%$ of the total heat dissipation $\mathrm{HD}^{\circ} \mathrm{C}$ (Omran et al.,2017 and 2019c, e). The processes of conduction convection and radiation are all dependent on a thermal gradient, thus as air temperature rises towards body temperature the thermal gradient is reduced and heat dispersion is less effective, in addition, the non-evaporative cooling will shift to evaporative cooling when the ambient temperature is equal or above body temperature as described by Khalifa (2003) \& Omran and Hamdon (2018). The shade reduced death losses to $33 \%$ and production losses of surviving cows to 50 $\%$ for cows without shadow (Hahn, 1981).

Factors that contribute to variation in temperature and humidity include housing material and construction, forced ventilation, and bedding type plying important role in animal production High-yielding dairy cows are the most sensitive to the influence of heat at the beginning of lactation and in cases when a body temperature is higher than $39{ }^{\circ} \mathrm{C}$ production of milk significantly falls (Ravagnolo and Misztal, 2000). Omran and Fooda (2012) reported that the buffalo was successful life in the reclaimed land with harsh conditions. Under conditions, the close house from clay and roof from maize stoke above unit of wood give appropriate temperature-humidity index (THI), physiological performance and production for buffalo cow in the reclaimed land. Omran et al. (2019e) reported that the semi-open System was a lower value of heat dissipation $\left(\mathrm{HD}^{\circ} \mathrm{C}\right)$ under an environment in Nile valley, and The best roofs were mat and maize stoke for two species buffalo and cow respectively. The cottonwood was a good bedded compared with rice straw to reduce emission gas under buffaloes with increased urine., Added that the dirt land only was good without any bedded this clary from results of respiration rate $(\mathrm{RR} \mathrm{r} / \mathrm{min})$, heat dissipation for animals $\left(\mathrm{HDA} /{ }^{\circ} \mathrm{C}\right)$ and gas emanation gas emission as nitrous oxide (No2/L) and Carbon dioxide ( $\mathrm{Co} 2 / \mathrm{L})$ ) for two species the values of buffaloes for all parameters were reduced compared with the cows. The milk production and lactation period LP/day for buffaloes and cows in (Table 8 and 9). 
Table (8). Mean \pm SE for total milk yield (TMY/kg) and lactation period (LP/day) as affected by type of roof for buffaloes and cows under environmental conditions in the Nile Valley. (Omran et al., 2019e).

\begin{tabular}{|c|c|c|c|c|}
\hline \multirow{2}{*}{ Type of roof } & \multicolumn{2}{|c|}{ Buffaloes } & \multicolumn{2}{c|}{ Cows } \\
\cline { 2 - 5 } & TMY & LP & TMY & $167.00 \pm 46.00^{\mathrm{b}}$ \\
\hline $\mathbf{1}$ & $1333 \pm 57.42^{\mathrm{c}}$ & $154.0 \pm 4.50^{\mathrm{c}}$ & $1483 \pm 319.19^{\mathrm{c}}$ & $143.34 \pm 4.37^{\mathrm{c}}$ \\
\hline $\mathbf{2}$ & $1005 \pm 56.45^{\mathrm{d}}$ & $158 \pm 4.28^{\mathrm{c}}$ & $1084 \pm 216.19^{\mathrm{d}}$ & $168.89 \pm 1.31^{\mathrm{b}}$ \\
\hline $\mathbf{3}$ & - & - & $1055 \pm 21.82^{\mathrm{d}}$ & - \\
\hline $\mathbf{4}$ & $632.5 \pm 30.00^{\mathrm{e}}$ & $133 \pm 4.23^{\mathrm{d}}$ & - & - \\
\hline $\mathbf{5}$ & $1050 \pm 50.00^{\mathrm{d}}$ & $175 \pm 17.00^{\mathrm{b}}$ & - & $162.00 \pm 1.6^{\mathrm{b}}$ \\
\hline $\mathbf{6}$ & $950.0 \pm 117.17^{\mathrm{d}}$ & $170 \pm 3.78^{\mathrm{b}}$ & $978 \pm 33.9^{\mathrm{e}}$ & $182.30 \pm 6.39^{\mathrm{a}}$ \\
\hline $\mathbf{7}$ & $2135 \pm 24.57^{\mathrm{a}}$ & $225 \pm 1.89^{\mathrm{a}}$ & $1809 \pm 251^{\mathrm{a}}$ & $180.48 \pm 5.56^{\mathrm{a}}$ \\
\hline $\mathbf{8}$ & $1732 \pm 71.13^{\mathrm{b}}$ & $211 \pm 4.06^{\mathrm{a}}$ & $1718 \pm 213.44^{\mathrm{b}}$ & \\
\hline
\end{tabular}

1: Palm leaves, 2: Wood, Rice Straw and Cottonwood, 3: Sheet metals, 4: Asbestos, 5: Wood and Canvas, 6: Cement, 7: Mat; 8: maize stoke

$(-)$ : non fond diary animal under this model of roof.

Mean values for each item with different superscripts in the same column are significantly different $(P \leq 0.05)$.

Table (9). Mean \pm SE for total milk yield (TMY/kg) and lactation period (LP/day) as affected by type of bedded for buffaloes and cows under environmental conditions in the Nile Valley. (Omran et al., 2019e).

\begin{tabular}{|c|c|c|c|c|}
\hline \multirow{2}{*}{ Type of roof } & \multicolumn{2}{|c|}{ Buffaloes } & \multicolumn{2}{c|}{ Cows } \\
\cline { 2 - 5 } & TMY & LP & TMY & $185 \pm 5.16^{\mathrm{a}}$ \\
\hline $\mathbf{1}$ & $1830 \pm 215.0^{\mathrm{a}}$ & $210 \pm 11.34^{\mathrm{a}}$ & $1905 \pm 209.4^{\mathrm{a}}$ & $145 \pm 1.89^{\mathrm{b}}$ \\
\hline $\mathbf{2}$ & $1183 \pm 59.5^{\mathrm{c}}$ & $179.75 \pm 4.30^{\mathrm{b}}$ & $875 \pm 66.0^{\mathrm{c}}$ & $171.36 \pm 1.96^{\mathrm{a}}$ \\
\hline $\mathbf{3}$ & $1394 \pm 59.2^{\mathrm{b}}$ & $188.6 \pm 4.26^{\mathrm{b}}$ & $1364 \pm 104.4^{\mathrm{b}}$ & - \\
\hline $\mathbf{4}$ & $1487 \pm 125.5^{\mathrm{b}}$ & $163 \pm 9.32^{\mathrm{c}}$ & - & - \\
\hline
\end{tabular}

1: dirty land, 2: Rice straw, 3: Mixture from cottonwood and rice straw, 4: cottonwood only.

Mean values for each item with different superscripts in the same column are significantly different $(P \leq 0.05)$.

The best for animal production and lower the effects of animal on environmental conditions the land under animal without bed, and the cow was more sensitive to effects of bedded to milk production compared with buffaloes on-seam bedded. Omran et al. (2019c) reported that the closed system housing was bad as a micro-environmental condition around an animal, the open system was the best selected to design house under climatic conditions in North of Delta for buffaloes and cows, the roof from sheet metal is a good roof with all parameter (heat dissipation, respiration rate, and gas emanation (GE)) from animal to house and vas versa, all parameters for two species mostly significant effects $P \leq 0.001$ except a type of land under animal for buffaloes. Added to the significant effect for total milk yield (TMY/Kg) and lactation period (LP/day) (P $\leq 0.001$ ), the open housing reduces the impact of climatic conditions on animal and vas versa, and the land from cement, with necessary cover sewage network and place of manure collection to biosafety these reduce the impact of animals on climatic conditions.

\section{9- Milk production, composition and quality:}

Buffaloes play a very important role in the dairy sector in Egypt. Major constituents of the milk namely the fats, proteins, sugars are high in buffalo milk and it is also rich in vitamins and minerals making it a great source of nutrition buffalo milk contains higher levels of total solids, crude protein, fat, calcium, and phosphorous and a slightly higher content of lactose compared with those of cows' milk. The high level of total solids makes buffalo milk ideal for processing to value-added dairy products such as cheese as reported by Claeys et al. (2014).

The changes in environmental factors like ambient temperature, relative humidity, wind speed, and solar radiation cause stress in lactating cattle, heat stress adversely affect both the quantity and quality of milk. the outside temperature of $35{ }^{\circ} \mathrm{C}$ the quantity of milk is decreased by $33 \%$ and at the temperature of $40{ }^{\circ} \mathrm{C}$ by $50 \%$ (West, 2003 and Rhoads et al., 2009). Heat-stressed cattle may try to reduce the body heat through thermoregulatory mechanisms which in turn affect feed conversion efficiency and lead to decreased milk production. Omran et al. (2017) under an environmental condition in middle Egypt on buffaloes at late gestation the THI index around animals was 58.64 (January to March) and after birth 69.33 (April to June until time of peak) reported that the value of milk yield $\mathrm{Kg} /$ day was $4.20 \mathrm{Kg}$, Fat $4.3 \%$, protein $3,59 \%$, lactose $4.3 \%$, total solids $13.3 \%$ and solids not fat $9.1 \%$, this decreased due to more sensitivity to buffaloes to cold stress and elevated this stress by added diets supplemented as ZAD increased the all values respectively $(5.8 \mathrm{Kg}, 6.7 \%$, $4 \%, 5.1 \%, 16.7 \%$, and 10\%). Fooda and Omran (2012) under different conditions in middle Egypt, the farms were located in different geographical regions, one in the village(farm one) and the other in reclaimed land(farm two) the THI index were 64.0 in the winter month and 82.4 in summer (farm one) and the other hand (farm two) were 55.6 and 64.0 respectively, reported that the means of total milk yield $(\mathrm{TMY} / \mathrm{Kg}$ ) and lactation period (LP/day) in farm one were higher than farm two while the persistency in farm one was lower than farm two. Added to, the estimates of the initial milk yield (a) were 51 and $56 \mathrm{~kg}$ in farm one and farm two, respectively. Concerning the rate ( $\mathrm{kg} / \mathrm{two}$ weeks) of increase to peak during the ascending phase (b), the higher rate was $1.32 \mathrm{~kg} /$ two weeks in farm one and the lower rate was $0.87 \mathrm{~kg} /$ two weeks in farm two. For 
the rate $(\mathrm{kg} /$ two weeks) of decrease during the descending phase $(\mathrm{c})$, farm one gave the highest decreasing rate $(-0.25$ $\mathrm{kg} / \mathrm{two}$ weeks), while farm two had the lowest decreasing rate $(-0.15 \mathrm{~kg} / \mathrm{two}$ weeks, and this clear that, the persistency value was high in farm two, although decreased of LP and TMY. $R^{2}$ value in farm one was higher than in farm one. Despite these conditions, the average daily milk is less than $1 \mathrm{~kg}$ only with increasing persistence. Many authors estimated lactation curve parameters for milk yield of Egyptian buffaloes using the nonlinear form of the incomplete gamma function in the large holder (Aziz et al., 2006 and Fooda et al., 2009).

\section{0- Water and feed intakes:}

Productive performance is the most important index out of various indices of animal adaptability to environmental conditions. This index is an outcome of water and feed intakes behavior, which is affected, greatly by stress factors mainly that of climatic and nutritional conditions. Water and feed intakes are affected markedly by ambient temperature (Omran et al. 2011a,b ,2013 and 2019b). There is a lack of research related to the implications of reduced water availability for landbased livestock systems due to climate change (Thornton et al., 2009). Several physiological changes indicate the response of dairy cows to heat which is manifested by the number of efforts reactions, including reduced feed intake increased water intake, evaporative water losses from the body, increased respiration rate, and altered endocrine functions (Calamari et al., 2007 and Omran et al., 2011a,c, 2013 and 2019b). Water salination could affect animal metabolism, fertility, and digestion.

Chemical contaminants and heavy metals could impair cardiovascular, excretory, skeletal, nervous, and respiratory systems, as well as the impairing, hygienic quality of production (Nardone et al., 2010). With climatic change under Egyptian conditions, a regular adjusting of water consumption is needed for both buffaloes and cows where is potentially the main ingredient in milk and meat production in Egypt. Under thermoneutral conditions, water intake equals water loss in the normal adult animal, while under heat stress the major physiological reaction is an increased water intake and consequently body water content., As water is lost through urine, skin, and respiratory vaporization under heat stress, a temporary water deficit with increased body fluids concentration stimulates the hypothalamic thirst center to control water consumption (Ashour, 1990, Ashour et al., 2007, Omran et al., 2013 and 2019b). Omran et al. (2019b) reported that the best climatic condition for buffaloes and cows was THI between 71- 74 under environmental conditions in Egypt and the higher consumption from the water was in (Lower Egypt) and the lower consumption was in (Upper Egypt). In addition to the cows were higher than buffaloes in consumption water and feed in the three climatic regions in Egypt (LE, ME, and UE) and through two the ages less than one year and more than one year.Omran and Fooda (2012) reported that the reclaimed land is called Abou-Suroor land. Its sandy land, they planted olive and Peanut. The animal feeding is depending on concentrate at the milking time and Alfalfa clover, alfalfa hay, and bean hulls were offered adlib in the winter, while in summer depending on concentrate at the milking time and Alfalfa clover, Alfalfa hay, and bean hulls and wheat straw were offered adlib. The water from wells (salinity 2500 to $3000 \mathrm{ppm}$ ) the animals were drinking twice/day in winter and were 3 times/day in summer without any diversity on animal productivity. Omran et al. (2019a) found that the Most animals of watering (92\%) by spouts was the salinity of water $400 \mathrm{ppm}$, and the higher values of water salinity were $3500 \mathrm{ppm}$ from well in reclaims area to watering green crops and buffalo and cow., needed under this condition water under shaded maintain suitable salinity of the water., without shaded the salinity increased during the day between 30 to 50 ppm. Ashour (1990) found that buffalo calves increased their water intake in summer than in winter by two folds as absolute values (39.2 vs. $20.1 \mathrm{~L} /$ day) and by three times relative values to metabolic body weight $(\mathrm{MBW})^{0.75}$, this increase in water intake (WI, L/day) with the hot condition is augmented by a behavioral eagerness to gulp copious cold water., due to reflects of the physiological role of (WI, L/ day) in counteracting heat stress by increasing water vaporization through the skin and or respiratory surface

Ashour et al. (2007) reported that the interaction between water intake and temperature showed no significant effect while the interaction between concentrate intake and the temperature had a highly significant effect on average daily gain (ADG/kg). This Contrast in those interactions proves that the major effect of temperature on growth is through control of feed intake (Fl/Kg). Omran et al. (2017) used product containing anaerobic bacteria and a mixture of natural cellulosic enzymes as a dietary supplement (ZAD) for buffaloes feeding reduced the harmful effects of cold waves through improving the postpartum physiological status and reducing the sensitivity of buffaloes to cold climatic Plasma thyroxin and triiodothyronine level is found to be decreasing during heat stress than in normal thermoneutral conditions. El-Masry and Marai (1991) reported that buffalos were more tolerant than Friesians to the environmental condition of Egypt; in addition to the buffalo, calves had poorer feed efficiency and higher dry matter intake in winter and higher growth rate in summer than Friesian calves ( $\mathrm{P} \leq 0.05)$. Omran (1999) reported that constant heat stress in a lab at $40^{\circ} \mathrm{C}$ increased water consumption per metabolic body weight (MBW) ${ }^{0.75}$ by $16 \%$ in buffalo calves and $25 \%$ in Friesian calves, added to the concentrate intake was reduced by $20 \%$ in buffalo and $18 \%$ in Friesian calves and reduced the average daily gain (ADG/kg) by $25 \%$ in buffalo calves and $20 \%$ in Frisian calves., The feed intakes as related to metabolic body weight showed that concentrate intakes were reduced in response to heat stress, from that pre-stress by $13 \%$ in buffaloes and $17 \%$ in Friesian per Kg (BW) 0.75 . In addition to the ratio of roughage to concentrate was higher in summer than winter in Friesian calves and buffalo calves being 31.3 vs. $29.8 \%$ for buffalo, 31.8 vs. $28.5 \%$ in Friesian.

\section{CONCLUSION}

We can conclude that buffaloes the first animal of climatic change, can be changed both morphology and histology of skin to maintain bioprocess and do not make any change genetically. Buffaloes changing by the thickness of skin, length of hair, number of hair follicles, the color of hair and skin to make acclamation with any conditions to make the buffalo's 
characteristic form suitable for any place to live. It's faster recovering from heat stress during few days and can acclimatize to transportation stress during the first year after transportation but need to three seasons to be acclimatized regarding total milk yield and curve of lactation. Under heat stress in a lab, the water capacity of rumen was lower compared with several respiration rates under stress in a minute, this gives an indicator to the performance of buffalo calves to maintain on body temperature by losing low quantity from water. The buffalo tolerant water salinity and lower consumption of water and feed intakes and lower methane emission. It can be live in the reclaimed land under harsh conditions. And it's tolerant salinity of water until $3500 \mathrm{ppm}$. It's feeding green crops watering as seam salinity. The feed and water consumption by Frisian calve was high compare with buffalo calves, this economically costly in the other hand, the buffalo calve was efficient and better maintained the physiological balance of the body which ensures no disruption leading to loss of animal and this uneconomic. It concluded The Buffalo can be make changed its morphology and histology to maintain bioprocess, can acclimatize under any environmental conditions around it; it is more adapted to hot conditions, and by supplementation diets tolerant cold weaves. With the climatic change, we can increase milk and meat production from buffalo without a drop in production or disruption on animals. With available suitable shades above animals, and shading watering to protect from solar radiation direction. We needed to increase of study on buffaloes between adaption and mitigation to lower the bad effect of climatic change (Fig. 2).

\section{Tolerant to higher salinity}

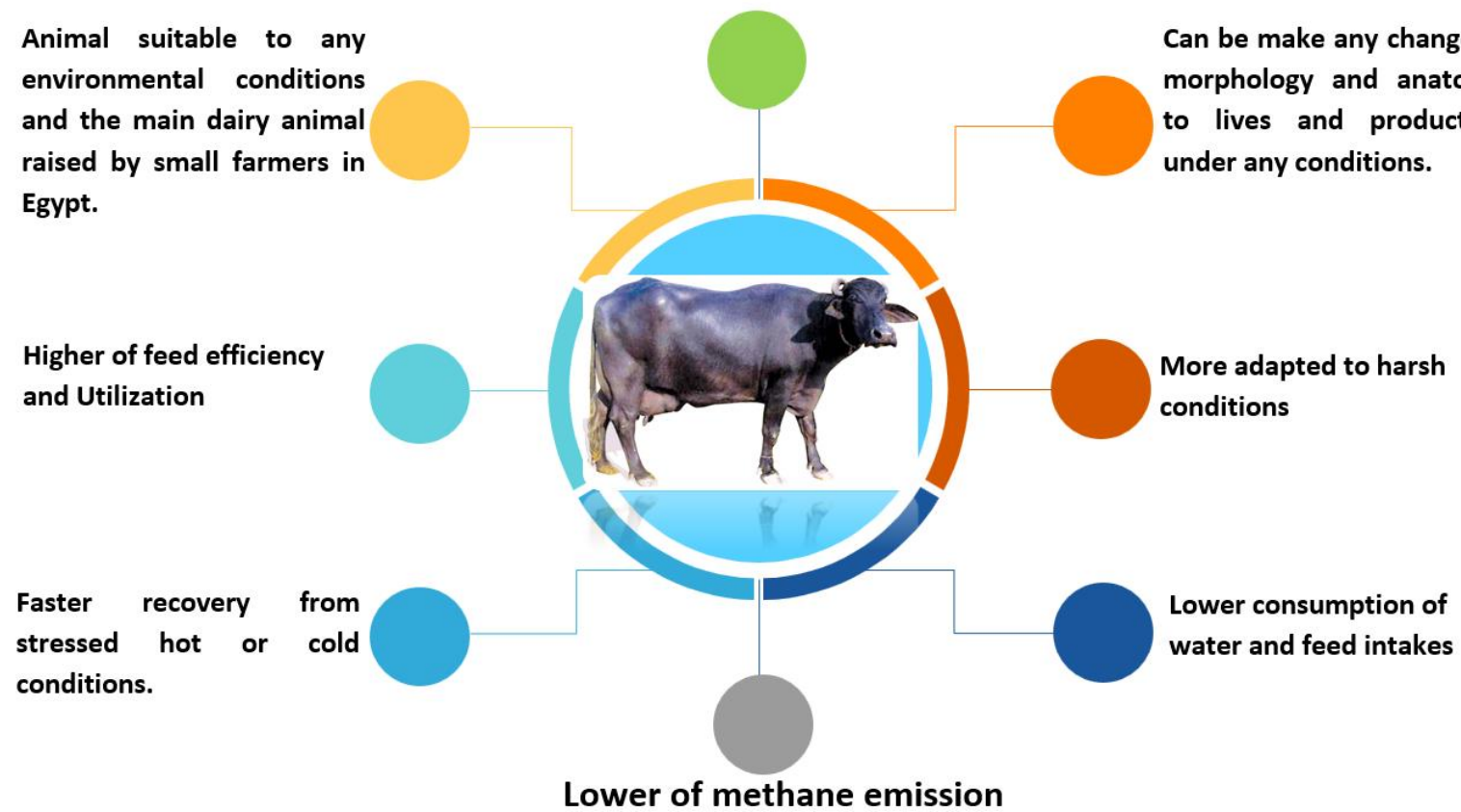

Fig. 2. The conclusion of this invited review.

\section{REFERENCES}

Appuhamy, J. A., France, J., \& Kebreab, E. (2016). Models for predicting enteric methane emissions from dairy cows in North America, Europe, and Australia and New Zealand. Global Change Biology, 22(9), 3039-3056.

Ashour, G., Hassan, L. R., Omran, F. I., \& Shafie, M. M. (2004). Thermo-respiratory responses hematological and hormonal reactions of buffalo and Friesian calves to the rise in environmental temperature. Egyptian Journal of Animal Production 41, 353.

Ashour, G., Hassan, L. R., Omran, F. I., \& Shafie, M. M. (2000). Growth performance of buffalo and Friesian calves under natural climatic and steady heat stress conditions. Journal of Agricultural Science, 25, 2503.

Ashour, G. (1990). Water balance in bovine as related to heat regulation (Doctoral dissertation, Ph. D. Thesis, Fac. Agric., Cairo Univ., Giza, Egypt).

Ashour, G. (1990). Water balance in bovine as related to heat regulation (Doctoral dissertation, Ph. D. Thesis, Fac. Agric., Cairo Univ., Giza, Egypt).

Atwa, S., Mourad, M., \& El-Sayed, H. M. (2019). Productive and reproductive performances of water buffaloes compared to those of Holstein and brown Swiss cattle in Egypt: a limited and oriented review. Animal Science Reporter, 12(3), 12-23. 
Aziz, M. A., Shalaby, N. A., El-Shafie, O. M., Mahdy, A. T., \& Nishida, A. (2006). Comparison between the shapes of lactation curve of Egyptian buffalo milk yield estimated by the incomplete gamma function and a new model. Livestock Research for Rural Development, 18(5), 2006.

Bohmanova, J., Misztal, I., \& Cole, J. B. (2007). Temperature-humidity indices as indicators of milk production losses due to heat stress. Journal of Dairy Science, 90(4), 1947-1956.

Borghese, A. (2011). Situation and perspectives of buffalo in the world, Europe and Macedonia. Macedonian Journal of Animal Science, 1(2), 281-296.

Calamari, L.; F. Abeni; F. Calegari and L. Stefanini (2007). Metabolic conditions of lactating Friesian dairy cows during the hot season in the Po valley. 2. Blood minerals and acid-base chemistry. International Journal of Biometeorology 52: 97-107.

Claeys, W. L., Verraes, C., Cardoen, S., De Block, J., Huyghebaert, A., Raes, K., ... \& Herman, L. (2014). Consumption of raw or heated milk from different species: An evaluation of the nutritional and potential health benefits. Food Control, 42, 188-201

Collier, R. J., Dahl, G. E., \& VanBaale, M. J. (2006). Major advances associated with environmental effects on dairy cattle. Journal of Dairy Science, 89(4), 1244-1253.

El-Masry, K. A., \& Habeeb, A. A. (1989, October). Thyroid function in lactating Friesian cows and water buffalo and its relationship with their milk yield in winter and summer Egyptian conditions. In Proc. 3rd Egyptian-British Conf. on Animal, Fish and Poultry Prod (pp. 7-10).

El-Masry, K.A. and Marai, I.F.M. (1991). Comparison between Friesians and water buialoes in growth rate, milk production and some blood constituents, during winter and summer conditions of Egypt. Animal Production, 53, 39.

FAOSTAT (2018). FAO Statistics Division. Fao, Rotme, Italy.

FOODA, T. A., \& OMRAN, F. I. (2012). Lactation curve and physiological reaction for egyptian buffaloes under different environmental conditions. Egyptian Journal of Agricultural Research, 90(3), 1297-1308.

Fooda, T. A.; I. A. Gebreel and Hoda M. Abd El-Raoof (2009). Study the change of lactation curve in Egyptian buffaloes. Egyptian Journal of Applied Science, 24(10B), 2009.

Gerber, P. J., Hristov, A. N., Henderson, B., Makkar, H., Oh, J., Lee, C., ... \& Oosting, S. (2013). Technical options for the mitigation of direct methane and nitrous oxide emissions from livestock: a review. animal, 7(s2), 220-234.

Ghavi Hossein-Zadeh, N., Mohit, A., \& Azad, N. (2013). Effect of temperature-humidity index on productive and reproductive performances of Iranian Holstein cows. Iranian Journal of Veterinary Research, 14(2), 106-112.

Hahn, G. L. (1981). Housing and management to reduce climatic impacts on livestock. Journal of Animal Science, 52(1), 175186.

IPCC (2013). Intergovernmental Panel on Climate Change. http://www.ipcc.ch/report/ar5/wg1/.

Khalifa, H. H. (2003, September). Bioclimatology and adaptation of farm animals in a changing climate. In Interactions between climate and animal production. Proc Symp (pp. 15-29).

Khalil A. A. and Omran F. I. (2018). Impact of climate change on temperature-humidity index values in Egypt. .International Journal of Science, Engineering and Technology V. (4) 1:1059-1064.

Kierstein, G., Vallinoto, M., Silva, A., Schneider, M. P., lannuzzi, L., \& Brenig, B. (2004). Analysis of mitochondrial D-loop region casts new light on domestic water buffalo (Bubalus bubalis) phylogeny. Molecular Phylogenetics and Evolution, 30(2), 308-324.

MALR. (2017). Statistics of livestock. The Ministry of Agriculture and Land Reclamation/Egypt.

Nardone, A., Ronchi, B., Lacetera, N., Ranieri, M. S., \& Bernabucci, U. (2010). Effects of climate changes on animal production and sustainability of livestock systems. Livestock Science, 130(1-3), 57-69.

Omran, F. I. (1999). Physiological reaction and growth performance of buffaloes and Friesian calves to heat stress (Doctoral dissertation, M. Sc. Thesis, Fac. Agric., Cairo Univ., Giza, Egypt, P 147).

Omran, F. I. (2008). Impact of thermo-physiological reaction on growth performance of buffalo calves (Doctoral dissertation, Ph. D. Thesis, Fac. Agric., Cairo Univ., Giza, Egypt, P 142).

Omran, Fayza I. (2013a). Histology \& meat quality of buffalo calves under heat stress. Egyptian Journal of Basic Applied Physiology., 12 (1): 99-111.

Omran, Fayza. I. (2013b). Changes in rumen and abomasum tissues and Rumen water capacity in buffalo calves Exposed to different thermal conditions. Egyptian Journal of Applied Science 28 (B).

Omran, F. I., Shafie, M. M., Ashour, G. H., Hassan, L. R., \& Youssef, M. M. (2011a). Physiological reaction and growth performance of buffalo and Friesian calves after recovery from heat stress. In Proceedings of the 4th Scientific Conference of Animal Wealth Research in the Middle East and North Africa, Foreign Agricultural Relations (FAR), Egypt, 3-5 October 2011 (pp. 78-94). Massive Conferences and Trade Fairs.

Omran, F. I., Ashour, G., Shafie, M. M., Youssef, M. M., \& Ahmed, M. M. (2011b). Effect Of Heat Stress On Body Composition Of Egyptian Buffalo-Calves. Egyptian Journal of Agricultural Research, 89(3), 1141-1149.

Omran, F. I., Ashour, G. H., Hassan, L. R., Shafie, M. M., \& Youssef, M. M. (2011c). Physiological responses and growth performance of buffalo and Friesian calves under chronic severe heat stress. In Proceedings of the 4th Scientific Conference of Animal Wealth Research in the Middle East and North Africa, Foreign Agricultural Relations (FAR), Egypt, 3-5 October 2011 (pp. 1-13). Massive Conferences and Trade Fairs.

Omran, F. I., ASHOUR, G., YOUSSEF, M. M., \& SHAFIE, M. M. (2011d). Responses of hematology, blood metabolites, mineral ions and hormonal profile to heat stress for Egyptian buffalo-calves. Egyptian Journal of Agricultural Research, 89(3), $1129-1140$. 
Omran, F. I., \& Fooda, T. A. (2013, November). Thermal discomfort index for buffalo and Friesian under Egyptian condition. In The 4Th scientific conference of Animal Production Research Institute (April), Cairo, Egypt (pp. 12-13).

Omran, F. I., Shafie, M. M., Ashour, G. H., Yousse, M. M., \& Hassan, L. R. (2013). Response of buffalo calves exposed to first and second acute thermal shocks. Egyptian Journal of Agricultural Research, 91(3), 1113-1128.

Omran, Fayza I, Mahgoub, A. A. S. and Fooda, T. A. (2017). Effect of biological additive on physiological and Production performance of buffaloes during Cold weaves stress in mid of the Egyptian valley. Egypt J. Agric. Res., 95 (4).

Omran, F., \& Hamdon, H. (2018). Transportation, Adaptive and Productive Performance of Transported Buffalo Herd in New Environment. Journal of Animal and Poultry Production, 9(3), 191-196.

Omran, Fayza, I.; Abolmaaty, S. M.; Fooda, T. A.; Abou-Seri, H. S.; Mahmoud, S. A.; Hassan H. A,Taqi, M. O.; Sahar A. Abd ElRahim; A. A. El. Giziry, A. A.; Ahmed, S. E. M.; Mahgoub, A. A. S.; Mohamed, M. Y.; Laila R. Hassan; Laila N. Eid; Osman, H. Z.; Hassanein, M. K. and Ammar, R. (2019a). Field study of animal production under environmental condition in nile valley and north of Delta. Proceeding of the 1st International Conference of Animal Production, September 10-14, 2019, Sharm El Sheikh City, Egypt (Proceeding of the 2nd International Conference of the Egyptian Association for Improving Egyptian Buffaloes, The 5th International Conference of Animal Production Research Institute". 35-52.

Omran, Fayza I., T. A .Fooda, and M. O. Taqi (2019b). Water and feed consumption and body weight of Egyptian buffaloes and cows under different regional climatic conditions in Egyptian Journal of Animal and Poultry Production, 10 (8): 261-270.

Omran, Fayza I.; Sahar, Abd El-Rahim A. and T. A. Fooda (2019c). Physiological and productive performance of Egyptian buffaloes and cows under different housing systems and environmental conditions in the North of Delta region. Proceeding of the 1st International Conference of Animal Production, September 10-14, 2019, Sharm El Sheikh City, Egypt (Proceeding of the 2nd International Conference of the Egyptian Association for Improving Egyptian Buffaloes, The 5th International Conference of Animal Production Research Institute". 20-34.

Omran, Fayza. I, H. S. Abou-Seri and Fooda T. A. (2019d). Phenotypic Description and Body Measurements for Egyptian Buffalo under Nile delta and Nile valley Region Climatic Conditions. Proceeding of the 1st International Conference of Animal Production, September 10-14, 2019, Sharm El Sheikh City, Egypt (Proceeding of the 2nd International Conference of the Egyptian Association for Improving Egyptian Buffaloes, The 5th International Conference of Animal Production Research Institute". 1-19.

Omran, F. I., Mahmoud, S. A., \& Fooda, T. A. (2019e). Impact of housing patterns on physiological and production performance for egyptian buffaloes and cows in Nile Valley. Journal of Animal and Poultry Production, 10(4), 89-94.

Omran, F. I., Khali, A. A., \& Fooda, T. (2020). Physiological responses and hematological aspects of buffaloes and cows under different climatic conditions in Egypt. Egyptian Journal of Agricultural Research, 98(1), 64-79.

Ravagnolo, O., \& Misztal, I. (2000). Genetic component of heat stress in dairy cattle, parameter estimation. Journal of Dairy Science, 83(9), 2126-2130.

Rebak, G., Sánchez, S., Capellari, A., Cedres, J., \& Patiño, E. (2010). Characterization of Buffalo Meat in Corrientes, Argentina. Revista Veterinaria, 21(1).

Rhoads, M. L., Rhoads, R. P., VanBaale, M. J., Collier, R. J., Sanders, S. R., Weber, W. J., ... \& Baumgard, L. H. (2009). Effects of heat stress and plane of nutrition on lactating Holstein cows: I. Production, metabolism, and aspects of circulating somatotropin. Journal of Dairy Science, 92(5), 1986-1997.

Rust, J. M., \& Rust, T. (2013). Climate change and livestock production: A review with emphasis on Africa. South African Journal of Animal Science, 43(3), 255-267.

Sarubbi, F., Baculo, R., Palomba, R., \& Auriemma, G. (2013). Estimation of the Methane Emission Factor for Buffalo Cattle and Bulls.

Shaffer, L., Roussel, J. D., \& Koonce, K. L. (1981). Effects of age, temperature-season, and breed on blood characteristics of dairy cattle. Journal of Dairy Science, 64(1), 62-70.

Shafie, M. M. and F. I. Omran (2018). Adaptivity of buffalo calves to differ thermal conditions. Egyptian Journal of Agricultural Research 96 (2), 703-714.

Shafie, M. (1993). Biological adaptation of buffaloes to climatic conditions. PUBLICATION-EUROPEAN ASSOCIATION FOR ANIMAL PRODUCTION, 62, 176-176.

Shafie, M. M. (1985). Physiological responses and adaptation of water buffalo. Stress physiology in livestock. Volume II. Ungulates., 67-80.

Shafie, M. M. (1993a). Biological adaptation of buffaloes to climatic conditions. Egyptian J. Anim. Prod., 176.

Shafie, M. M. (1993b). Environmental effects on water buffalo production. World Animal Review FAO, 77, 21-25.

Thornton, P. K., Farrow, A., \& Jones, P. G. (2007). The temporal dynamics of crop yield responses to climate change in East Africa.

West, J. W. (2003). Effects of heat stress on production in dairy cattle. Journal of dairy science, 86(6), 2131-2144.

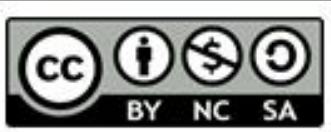

Copyright: (c) 2021 by the authors. Licensee EJAR, EKB, Egypt. EJAR offers immediate open access to its material on the grounds that making research accessible freely to the public facilitates more global knowledge exchange. Users can read, download, copy, distribute, print or share a link to the complete text of the application under Creative Commons BY-NC-SA 4.0 International License. 


\title{
الجاموس والتغيرات المناخية: . تأقلمه مع البيئه وتاقلم البيئه معه
}

\author{
فايزة ابراهيم عمران البحران \\ معهد بحوث الإنتاج الحيواني ، مركز البحوث الزراعية ، الجيزة ، مصر \\ fayza.omran@yahoo.com بريد المؤلف المراسل*
}

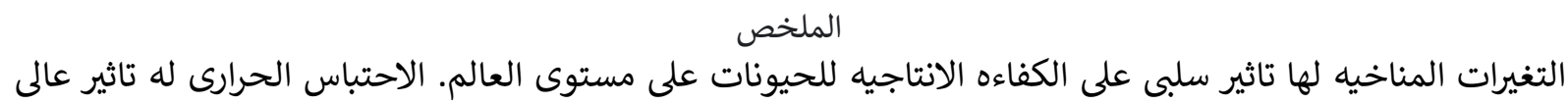

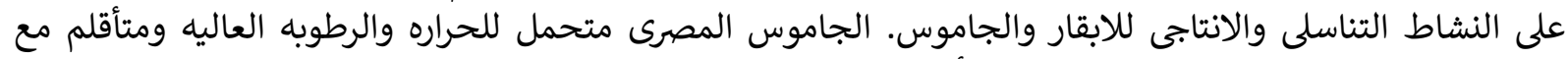

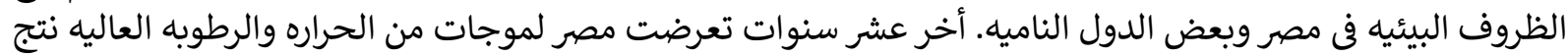

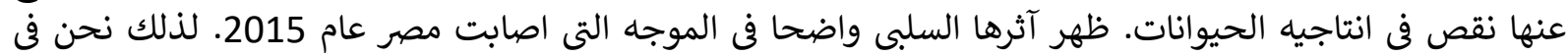

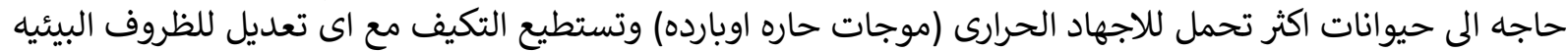

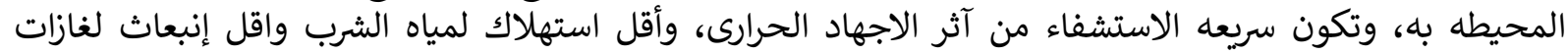

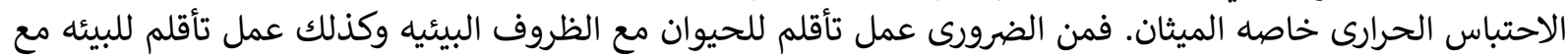

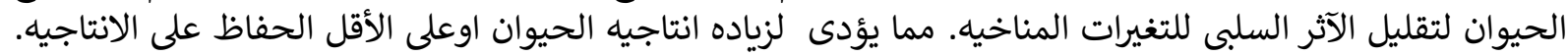

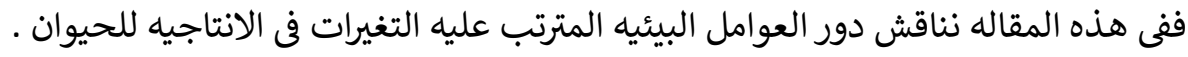
الكلمات المفتاحية : الجاموس، دليل الحراره والرطوبه، التغيرات المناخيه. 